\title{
BERLIN AS A CREATIVE FIELD: DECONSTRUCTING THE ROLE OF THE URBAN CONTEXT IN CREATIVE PRODUCTION
}

\author{
MARCO COPERCINI \\ Institute of Economic and Social Geography, Potsdam University, Germany
}

Manuscript received: April 15, 2016

Revised version: October 9, 2016

\begin{abstract}
CoperCINI M., Berlin as a creative field: Deconstructing the role of the urban context in creative production. Quaestiones Geographicae 35(4), Bogucki Wydawnictwo Naukowe, Poznań, pp. 121-132.

AвSTRACT: The relation between creative activities and the cities in which they are concentrated is that of mutual influence and dependence. This kind of dynamics is well described by the concept of the creative field by Scott $(2006,2008$, 2010, 2014). According to this concept, there is a shared relational context among creative actors in a given place, as well as between them and the local socio-economic-institutional context. Consequently, the economic profile and innovation capacity of a city are determined by the main sectors based there. In this paper, I discuss the role of the creative field in developing the relation between the city of Berlin and creative actors of the fashion design sector, as well as elements of the creative field that are considered relevant by fashion designers in their creative work. This perspective allows the underscoring of some relevant drivers that have made Berlin one of the most relevant places for fashion design in Germany and the whole of Europe. This research has been supported by administrative data from the period 1990-2015, along with personal interviews in the fashion design sector. Shown are not only the existing relations between the urban context and the creative activities of designers, but also how the development of the creative field of the city might be influenced. Consequently, the creative work of fashion designers and their location decisions have to be considered in relation to the creative field as a dynamic combination of variable elements that influence, and are influenced by, each other.
\end{abstract}

KEY wORDS: creative field, fashion design, urban context, Berlin

Marco Copercini, Institute of Economic and Social Geography, Universität Potsdam, Germany; e-mail: copercin@uni-potsdam.de

\section{Economic agglomeration and urban growth}

Cities have always been places of creativity and innovation, which is as true today as it was in previous historical periods (Hall 1998). The creative forms of production, as well as knowledge-intensive sectors, are characterised by their relations with urban centres, especially big ones (Krätke 2011), which function as catalysts for creative processes.
This relation between cities and creative- and knowledge-intensive activities can be described as cognitive-cultural capitalism (Scott 2014), which identifies economic activities based primarily on the cerebral capacities of the labour force. Economic activities of cognitive-cultural capitalism are seen as the driving force of the next wave of urban economic growth, the central element of this process being represented by the job-generating capacity of cities and human-capital-intensive sectors, as well as the creative impulses that are generated by the agglomeration 
and interaction of local actors (Moretti 2012; Scott 2014).

Creative activities and creative actors are distributed unevenly in space and tend to concentrate in urban centres, which then become regional poles of innovation and social variety (Boschma, Fritsch 2009), constituting central elements for potential economic growth. Cities are traditionally places of encounter between people, ideas, and cultures, and, in some cases, a creative atmosphere can develop that stimulates and facilitates the recognition of innovation in specific sectors, and gives a city a central position in a specific historical period (Jacobs 1961; Hall 1998; Merkel 2008; Mundelius 2008). A creative city, or an agglomeration of cultural-cognitive capitalism activities, can therefore stimulate ideas and information exchanges that potentially lead to innovation. This is not only characterised by economic activities, but also has aspects that are not primarily related to production activities (like private spheres of individuals, their lifestyles, and their consumption habits), creating an open environment for entrepreneurial and cultural activities (Zukin 1995; Bagwell 2008; Pratt 2008; Evans 2009).

Creativity and its expression forms are not simply the result of the cerebral activity of single individuals (Stryjakiewicz et al. 2014), but are also activated and projected by relations that local actors develop in their working activities, social relations and urban context - hence, what is presented as a creative field (Scott 2006a, 2008, 2010, 2014). As Scott points out (2014: 9), "today, forms of urban creativity reside substantially in the specific socioeconomic relationship built into the new cognitive and cultural order". Therefore, in this sense, the production processes within creative sectors are related to urban spaces in a multi-layered and multidirectional structure.

In this paper, I discuss the sectoral and spatial dynamics of fashion design in Berlin, focusing on the relation that the creative actors in this sector (fashion designers) have with the city, and on which elements of the city are considered relevant for the location decision of their creative activity. In order to accomplish this, I use the theoretical framework of the creative field, which represents the result of interactions between creative actors and the city, as well as changes in the economic and social structure of the city. The creative field is therefore characterised by path-dependent dynamics. However, when describing the relations between the creative field and actors, Scott (2006a, 2008, 2010, 2014) tends to refer to creative actors or creative sectors in general, and not to specific sectors.

Consequently, in order to integrate this theoretical perspective, I argue that the relations of actors with the creative field have to be considered for a specific creative sector, as they might change from sector to sector. Furthermore, elements of the creative field recognised as relevant by creative actors might have different natures and involve the presence and activity of other creative actors (from the same or different sectors) as well as elements of the socio-economic context of the city. This perspective allows one to underline some elements that have driven Berlin from the dismantling of its industrial-based model to becoming one of the most relevant places for fashion design (and creative industries in general) in Germany and the whole of Europe.

\section{Methodology}

The reflection on the role of the urban context in creative production starts with two perspectives concerning drivers of agglomeration processes of creative actors: one identifies creative people and the other the local job market as a central feature for economic growth. The concept of the creative field has to be positioned beyond those two perspectives, as it does not focus on single causal explanations of urban economic dynamics. A creative field is the unique result of interactions between creative actors, socio-economic dynamics, and historical processes in one place. Therefore its analysis requires different kinds of data: for the economic structure as a whole and for the chosen creative sector (in this case fashion design), in order to understand their interaction that actually contributes to generating the creative field itself.

The analysis of the creative field of the city and its perception by fashion designers is supported by statistical data on the city's economic and social structure and by qualitative data in the form of personal interviews conducted with Berlinbased fashion designers. Fashion design was chosen because it is one of the most important 
sectors within the creative industries of Berlin and has a long tradition in its economy. All interviews were conducted between 2011 and 2013 with 25 Berlin-based fashion designers and are between 30 and 80 minutes long. ${ }^{1}$ The different designers interviewed are indicated in the text with IDs and the number of the interview (e.g., ID03 refers to the third designer interviewed).

What is understood as "creative industries" and what kind of sectors fall under this concept cannot be defined in general, but the definition has to be based on local experience and practices (Pratt 2005). In Germany, there is a shared definition at the federal level in which sectors are considered part of creative industries (BMWi 2012; Enquete-Kommission 2007). Therefore, as fashion design is part of this definition, it goes beyond the scope of this paper to discuss the definition of creative industries and, for the same reason, the terms "creative industries" and "cultural and creative industries" will be used here as synonyms.

\section{Two perspectives on drivers of agglomeration processes of creative actors}

Before focusing on interactions among actors and between actors and the city, let me discuss why creative people and activities tend to concentrate in specific cities. The existing relation between location decisions of creative actors, their economic activity and urban economic growth can be explained by two lines of argumentation that identify different central elements as drivers of agglomeration processes of creative actors: creative people on the one side and the local job market on the other. There are therefore two main approaches to revitalising the local economy of urban areas, according to Moretti (2012): one consists of attracting workers in the hope that more companies will follow (e.g. improving the quality of life and attractiveness in the eyes of specific professionals), while the other focuses on attracting companies, hoping that workers will follow (e.g. with fiscal advantages; see

As some interviews were conducted in German, direct quotes from ID09, ID03 and ID19 in this paper are translated into English. also Boschma, Fritsch 2009; Stryjakiewicz 2010). Shared by both perspectives is the idea that cities are places where creativity and innovation concentrate, and that these elements are central in defining regional economic production structures (Hoffmann, Lompscher 1998: 252). These two perspectives are discussed briefly below.

\section{Jobs follow people: amenities}

During the last decade the argument has been raised that creative people tend to be concentrated in a particular city because of its specific amenities and characteristics. One of the most authoritative voices for this line of thought is Richard Florida. He believes that the central actor for urban economic growth is the creative class, a heterogeneous group of highly specialised workers and actors involved in artistic activities that tend to focus in urban areas where there is a good quality of life and a stimulating environment to spend their free time (Florida 2002). Furthermore, a climate of tolerance and local cultural opportunities are also highly valued by creatives (Florida 2002), and other authors have considered other elements of the urban environment as crucial to attracting creatives, such as the climate (Glaeser 2005) or urban attractions (Clark et al. 2002). Therefore, in this type of dynamics, work becomes a consequence of the presence of creative people; as a result, companies tend to cluster where there are creative actors. This leads other companies, also from different related sectors, to relocate to those areas. The presence of creative actors attracts more creative people as well as companies interested in taking advantage of this agglomeration. The pillars that explain the dynamics of urban economic growth from this perspective are talent, technology, and tolerance (Florida 2002). Therefore, from this point of view, a region should be attractive to the creative class in order to favour innovation and economic growth, as the concentration of creative actors is not only the central element of entrepreneurial success, but also that of urban economic growth (Youl Lee et al. 2004). The concentration of different kinds of creatives and the presence of useful infrastructure for creative sectors generate a local creative milieu in the city in which creatives can operate and interact, consequently contributing to entrepreneurial and local "economic success" 
(Landry 2000: 133). Ergo, creativity and personal interaction, from this perspective, become preconditions for economic growth, especially in creative and innovative sectors. Cities that intend to improve upon their competitiveness, which is the underlying message, should focus on elements of the local context supporting a local climate of tolerance and openness that can potentially attract creative actors (Boschma, Fritsch 2009).

\section{People follow jobs: the job market}

From a viewpoint different to the one that positions amenities and creative people's choices regarding their free time as the central driver for agglomeration processes and urban economic development, other authors see the job market and companies' decisions as the driving element for urbanisation processes and economic competitiveness for both regions and companies (Storper, Scott 2009; Moretti 2012; Scott 2014). The potential availability of jobs represents the central element in the settlement decision of actors, while amenities and related services can be made available or developed in a further step. However, they are mainly a consequence of the presence of companies and creative actors, and not a driver of their presence. Amenities do not represent, from this angle, a central element in the location decision-making of creative and knowledge-intensive companies. Therefore, a city builds its competitiveness and power of attraction primarily on the dynamism of locally-based companies and the market, and only secondarily on cultural and leisure activities. For companies, spatial concentration reduces transaction costs and allows high specialisation and vertical disintegration in production processes, generating urbanisation economies (Storper 2013: 36) that attract new companies and new, specialised workers (Moretti 2012).

Even though the whole production network has reached a global scale, the most creative and human-capital-intensive phases of production processes tend to focus in specific cities, contributing to the specialisation of the economies of urban areas. Actors increase their competences via their reciprocal (formal and informal) interactions (Moretti 2012), while simultaneously developing symbolic and cultural elements that not only characterise business activities, but are also reflected in the creative products of that city (e.g.
Hollywood films, Broadway musicals, Parisian fashion; Scott 2008; Storper 2013). Undoubtedly, cities with a solid economic basis in creative and innovative sectors also tend to be culturally stimulating and open. However, the cause and the effect should not be confused, as often cities with dynamic economic foundations in innovative sectors also tend to be attractive, but it is not always the other way round (Moretti 2012).

\section{The creative field of the city and its path-dependent nature}

Interactions between creative activities and the city, as well as their impact on the urban economy, have a complex and multi-layered nature and are at the very centre of the understanding of creativity-driven urban economic development, not to mention creativity itself (cf. Hall 1998; Landry 2000; Florida 2002; Merkel 2008, 2012; Scott 2010, 2014; Krätke 2011; Storper 2013). Creativity plays a relevant role in the understanding of entrepreneurial activities, especially in the creative- and knowledge-intensive sectors, as the immaterial resources that are generated from local interactions increase not only productivity and competitiveness for the companies in an agglomeration, but also the attraction forces of the city (Moretti 2012). In this sense, the city becomes a place where creativity is generated, applied, and, at the same time, influenced by the creative activities taking place there. This dynamics is described by the concept of a creative field (Scott 2006, 2008, 2010, 2014), as it underscores that creativity-based economic activities depend on different factors that can influence each other without implying deterministic causal relations.

The creative field "is represented by sets of industrial activities and related social phenomena forming spatially differentiated webs of interaction that mould entrepreneurial and innovative outcomes in various ways. .... Both the field on the one side and its effects on entrepreneurship and innovation on the other are reflexively intertwined with one another" (Scott 2006b: 54). This definition stresses the importance of social interactions in the different contexts in which entrepreneurial and creative actors develop a diffused creative atmosphere, as well as the reflexive effects that the interactions of those actors have on 
the creative field. Individuals tend to internalise elements of their environment and reflect them in their creative production and social interactions (Scott 2010: 119).

In another definition, the creative field is described "as a system of cues and resources providing materials for imaginative appropriation by individuals and groups as they pursue the business of work and life in urban space. But it is also a sort of canvas on which creative and innovative acts are variously inscribed" (Scott 2010: 121). Here the creative field is a source of inspiration for creatives and the background for their actions while also being shaped by those actions. Hence, knowledge production and exchange among actors in an agglomeration is the result of exchanges in social and professional contexts. The relation between creativity and innovation is socially constructed, not causal. Creativity, which also has a component in the intellectual capabilities of single individuals, requires a context that not only favours it, but that also helps to identify creative results and their value or application. Therefore, in a specific context, some forms of creativity are more highly valued than others, so that innovations in one sector are more supported than others (Scott 2006: chapter 2; Scott 2010). It follows that the creative field is made up of three different levels: networks of firms and workers and their interactions; infrastructural and social capital facilities (e.g. schools and universities); as well as norms and culture and conventions that develop in a local production agglomeration (Scott 2006a: 8).

The creative field and its related economic development, due to their relation to locally-based actors and contextual elements, demonstrate path-dependent behaviour, and it follows that the economic profile and innovation capacity of a city are determined and directed by the main sectors based there (Hall 1998; Scott 2008; Storper 2013). ${ }^{2}$ In the concept of the creative field, creativity is understood as a combination of personal qualities and social interactions. Actors are embedded in a socio-institutional context that influences the stance on innovation processes and interpersonal knowledge exchange. It is the result

Examples are Detroit for automotive production, Silicon Valley for the semiconductor industry, Los Angeles and Hollywood for film production, London for finance, and Paris for fashion. of material and immaterial elements that together stimulate creativity in local actors; therefore, a creative field cannot be identically reproduced somewhere else and is, in this sense, characterised by path dependency (Scott 2010). The development of specific sectors and the related specialisation of the local job market drive creative energies and the innovation orientation. Hence, it is essential to understand the need for the recognition of creative results, because, when a specific sector is highly represented in a city, creative impulses for this sector are sought after and promoted, while in other sectors they are not.

In this sense, it is more feasible and requires less effort to develop or specialise a sector already present in a city's economy than to try to change it completely. Actors in the creative field are linked to the local sectoral production system through the labour market, local knowledge exchanges, and production (Storper, Scott 2009; Storper 2013), so that the process of knowledge creation and learning is extended at the territorial level (Boschma 2004). The creative field, sector agglomerations and urban economies are related within this path-dependent structure, as "cultural regions specialise the way firms do, and ideas that are consistent with the core ideas defining the region will have a survival advantage. The reason for this is that an environment filled with semantic associations, symbolic meanings and cultural representations that reflect the core set of ideas can trigger people to perceive a new idea as being consistent with that set than when such associations are absent" (Staber 2008: 573). The relation between the city and creative economies is therefore related to the uniqueness of the place and its historical evolution, as it is very difficult, or even impossible, to recreate the same exact conditions for a specific creative field in a different location (Molotch 1996). The case of Berlin should therefore be approached from this perspective.

\section{Berlin as a creative field}

In order to identify the creative field of the city, along with the historical, social, and economic variables that have contributed to shaping it, as well as the relation between creative actors and the creative field, it was decided to combine 
quantitative data on the city of Berlin and personal interviews with creative actors. The quantitative data are indicators of elements that shape the creative field with its stimulating atmosphere and those of the economic profile of the city, while the qualitative data are from interviews I have conducted with fashion designers, taken here to be representative creative actors of the city's sector of creative industries.

\section{The perspective of the socio-economic structure of Berlin}

The historical features of the last several decades in Berlin, and with them the economic and social features, are unique and diverge from those of the other European capital cities. During the time of the city's division (1961-1989), the two halves faced different trajectories: West Berlin had almost no supra-regional relevance, with the exception of the subventionary cultural sector (Görnig, Häusserman 2002), while East Berlin was the most important city in the German Democratic Republic, where a third of all workers in the service sector were concentrated (Gornig 2012). After the reunification, East Berlin has lost its central role in the supra-regional industrial sector, and many industries in West Berlin, financed by federal support, have closed because of their structural weakness (Krätke 2004). From the 1990s on, the city's economy has been characterised by a higher unemployment rate than in the other German metropolitan regions, being also one of the highest in the nation. Moreover, during the 1990s, the "traditional" economic sector defined the urban economy (Krätke 1999; Krätke, Borst 2000), as the city struggled to establish a new economic identity. Despite the growth of the last decade, Berlin still has a weaker economic position than the other German metropolitan areas and one of the highest unemployment rates, though constantly decreasing since 2010 (14\% in 2010 and 11\% in 2014; Amt für Statistik... 2011, 2012c, 2013, 2014, 2015).

The distribution of workers among the different sectors of the Berlin economy has changed in the last 25 years. Even if the general number of workers changed only slightly between 1991 and 2014, employment in industrial sectors decreased (from ca. $40 \%$ to ca. $18 \%$ ), while in service sectors it increased (from ca. $60 \%$ to ca. $82 \%$ (Amt für
Statistik... 2011: 73; Amt für Statistik... 2015: 79). ${ }^{3}$ Those changes reflect the transformation of economic and production functions that took place in Berlin after its reunification.

From 2000, and especially from 2005, the Berlin economy has been on the rise, growing faster than in the other German regions (regarding the GDP and the number of workers), even if it has remained under the national average (Statistische Ämter des Bundes und der Länder 2016; Brenke 2010). Entrepreneurial activities in Berlin are characterised by high dynamism, and the opening and closure rates of new companies is higher than in the other German metropolitan regions (Gornig 2012). ${ }^{4}$

The three sectors that contribute the most to the economic growth of the city are tourism, knowledge-intensive activities, and creative industries (Krätke 2011; Gornig et al. 2012). Actors of creative industries and knowledge-intensive sectors tend towards spatial concentration, and creative activities especially cluster in the inner part of the city, with actors of similar or complementary sectors spatially nearby (Krätke 2004; Heebels, van Aalst 2010). This kind of concentration increases knowledge exchange among creative actors as well as social interactions that stimulate the activities of the urban creative field.

Another element that contributes to shaping the city's creative field is provided by the population of Berlin, as it is relatively young and has a strong cosmopolitan component. In the last two decades $^{5}$, the bigger age group has been that between 25-45 years old, while residents between 18 and 25 years old comprise the third group (after that aged 45-60; Amt für Statistik... 2012a, 2015).

3 The expression "industrial sectors" includes the following statistical administrative categories: production industries, manufacturing trade and construction industry, while "service sectors" embraces the categories: commerce, hotels and restaurants, and transport, financing, renting, and service providers, as well as public and private service providers.

According to the author, $36 \%$ of Berlin-based companies were opened after 1995, and $47.5 \%$ were closed. Therefore, if, on the one hand, this dynamism is a positive feature of Berlin, on the other hand, it might also suggest entrepreneurial incapability and a structural market weakness.

Data for 1992 and 2014. 
Berlin residents represent 160 nationalities that cover all five continents, although the larger part comes from European countries and the Mediterranean region (Amt für Statistik... 2012a). These features are more evident in the inner city where most activities in fashion design and creative industries in general also concentrate: here, the biggest age group is that between 18 and 45 years old. In this area, a lower average age and a greater cultural variety can be found, and, if the east-west division is considered, the eastern districts are the ones with a higher concentration of foreigners (Amt für Statistik... 2012a).

Besides the age and nationality, Berlin's population is characterised by immigration and emigration as well as internal migration, so that a significant part of its inhabitants (from a statistical point of view) have changed. In fact, between 1995 and 2012, from 115,267 to 164,577 new residents (from Germany and abroad) came to Berlin every year, while from 106,881 to 133,335 people left the city (Amt für Statistik... 2012b). If we hypothesise that in Berlin, a city of about 3.5 million inhabitants, the people who come are different from those who leave, then, after ten years, approximately a third of the population would have changed. This high mobility is to be found in the group between 20 and 35 years old, because young age groups, both Germans as well as foreigners, often come to and go from the city (Amt für Statistik... 2012b). Therefore, in the inner districts of the city, not only the creative companies and actors, but also a significant portion of young and international residents tend to concentrate.

The sector of creative industries in cities and Berlin has a relevant role at the national level. Creative industries in Germany have grown rapidly over the last ten years (especially between 2009 and 2011), accounting for 3.2\% of the sales volume generated in Germany in 2013 (BMWi 2015), while representing $7.6 \%$ of the German economy (BMWi 2015) and employing about 1,037,100 workers (BMWi 2015). Around $10 \%$ of all creative workers in the German creative sectors are concentrated in Berlin (Brenke 2007; Senat WiTF 2014). The sectors have also grown faster than in other German cities (Geppert, Mundelius 2007; Senat WiTF 2008): between 2000 and 2005 it grew by 30\% (Geppert, Mundelius 2007), while between 2009 and 2012 the growth rate decreased to $14 \%$ (Senat WiTF 2014: 6). This rapid growth is partially related to the fact that these sectors are characterised by a small size of companies, as more than half are one-person firms, at least in Berlin (Geppert, Mundelius 2007; Mandel 2007; House of Research 2015), that both compete and cooperate with each other. This is also reflected in the general increase in self-employed workers (Brenke 2010) and small enterprises.

However, Berlin is characterised by a concentration and activity of creative actors as well as flows of young and international people. This dynamism also has to be related to the relatively low costs of renting living and commercial spaces (for private or commercial activities) that have characterised the city since the reunification (House of Research 2015). Even though the perception of this situation started to change as creatives started to feel the pressure of swelling living costs (House of Research 2015), the density of creative activities is still a vital element of the urban economy in Berlin. However, an open question is what influence a rise in living costs would have on the young population and creative actors of the city.

\section{The perspective of fashion design}

The fashion design sector contributes to defining the profile of Berlin in creative industries, largely due to the concentration of actors of this sector in the German capital (Statistisches Landesamt 1991; Amt für Statistik ... 2015). ${ }^{6}$ At the national level, fashion design is one of the sectors of creative industries with the highest number of companies, number of workers, and turnover volume (BMWi 2012). The design sector, within which fashion design is listed, is one that, between 2002 and 2014, showed the highest growth rate in company formation in Germany

\footnotetext{
6 In Berlin there has been a steady, rapid decrease in industrial activities in apparel and textile production since 1990, dropping from 84 companies and 4,231 workers in the textile industry and 175 companies and 3,989 workers in the apparel industry in 1990 to five companies and 501 workers and three companies and 178 workers, respectively, in 2014. Out of the decrease in industrial activities has grown the activity of creative actors, and fashion designers in particular, and in this sense the change reflects the transformation of the city's economy.
} 
(BMWi 2015). ${ }^{7}$ This is also true for Berlin specifically, where the design sector, like cultural and creative industries in general, has been growing faster than in other German metropolitan areas (Geppert, Mundelius 2007; Gornig et al. 2012).

Fashion design in Berlin grew rapidly until 2010 and continued to do so in the following years (Gornig et al. 2012; Senat WiTF 2005, 2008, 2014), making Berlin a city with the highest concentration of fashion companies in Germany (Berlin Partner 2013). The density of actors in the fashion-design sectors is due not only to designers, but also to fashion-related events (e.g. the Berlin Fashion Week, which has taken place twice a year since 2007), fashion schools (there are now 13 institutions that offer fashion-related courses), and other creative actors related to the work of fashion designers (e.g. photographers, graphic designers, and models).

Fashion designers are focal creative actors in this sector, and since they work with their own labels they are entrepreneurs as well. Therefore, elements that play a role in their relation with their urban environment and elements of the creative field perceived as relevant to their activity are crucial for understanding aspects that are more valued by designers in their creative and entrepreneurial relations with the city of Berlin. Through personal interviews with fashion designers are identified motives of those creative actors for choosing Berlin as their place to work and live, as well as elements which stimulate their creativity, in order to understand the binding aspects of their creative work with the city. In other words, what elements and aspects of the urban creative field are recognised and valued by the designers as relevant to their work.

The elements of the creative field that are relevant to a fashion designer can be divided into three categories: (1) aspects related to the historical and economic dimensions of the city, (2) the concentration of fashion designers and other creative actors in Berlin, and (3) the socio-cultural variety and the relatively young age of the population affecting everyday life.

The historical development of the city in the last decades has led to the availability of space

\footnotetext{
However, between 2012 and 2014 the highest growth rate was recorded in the software sector and the games industry, while the design sector claimed third place.
}

as well as relatively low rents and living costs compared with other German cities. ${ }^{8}$ The 'empty' spaces and the diffused construction projects are also seen by designers as stimuli for their creativity, as sources of inspiration for creative processes:

So far, Berlin (...) has been a place characterised by incompletion; I mean, the fact that it is full of holes, of incomplete and moving things (...). Furthermore, I am an artist, so I am particularly sensitive to this point, this movement and half emptiness, or half fullness, of things that have surrounded me have always put me in a creative state, because it pushes my brain to complete, as you are not in Paris, where everywhere you look is clean, golden, and lacquered, finished. In Paris, you have to make a bigger effort to be creative. Of course, you can be creative anywhere, but, in the unfinished, (...) in an empty space is where you can think of what doesn't exist. If you are in a full, completed space it is harder. Berlin for me was this; it had this specific function of being, with its incompletion, the place that allowed me to invent the new. (...). Berlin, for me, has allowed me to create something that I wouldn't have been able to create in another place in Europe and at a ridiculous cost, compared with what it would have cost in Milan (ID09).

Next to the inspiration from the physical urban environment for creative processes, the relatively cheap living and the availability of free space have two main advantages for designers: on the one hand, they allow a person to live on less money and therefore allow the designer to earn less and still be able to pay for an atelier and shop, or to finance it with a part-time job if their design activity doesn't finance all of it. On the other hand, less cost pressure allows more experimentation and the trying out of new ways of working without many economic consequences in cases of non-success. It was described by a designer in the following interview:

I think there are a couple of reasons. First of all (...) I think Berlin is well-positioned in Europe. It

8 This situation and its perception are now, however, rapidly changing (House of Research 2015; Caspari 2015). 
has a very good reputation, it's a very creative city in a way, there's a lot of inspiration if you want, and it's a little bit off the centre of fashion. So, for me at least, being a new brand, it's a little bit easier. I was able to make a few mistakes and correct them and not be at the centre of attention. If you start a brand in Paris and you create a collection, and the collection is not nice, or if you make a mistake, or your quality is not perfect, you don't get a shit of a second chance. In Berlin, I had the opportunity to work, to try, to make mistakes, to correct them and still not burn myself out. Another aspect is an economic aspect. It's much cheaper to start a business in Berlin and to live in Berlin, rather than to live in Paris and to start a business there - everything costs more. To have a shop like what I have here in Paris, I think I would need to pay maybe five times more than I pay here, both to make it and for on-going costs. So, that's a very practical choice that I have made. I wanted somewhere where I could create my stuff that was not going to be detached completely from the fashion world, but not going to be completely in the centre of it, and I could afford to see my ideas come to life without burning, because I had no, let's say, business experience before I started this, only creative experience, so the business part was very new for me and I knew my resources were quite limited. So, if I were to start a business in a place where every day costs so much money, it would be very dangerous for the success of the business (ID07).

Therefore, contained costs also allow more entrepreneurial mistakes and give a designer the opportunity to learn from them and try out different ideas.

The relatively low living and rental costs of ateliers and shops allow designers to afford opening costs of their activities for a longer time than in other cities, so they feel the pressure of fixed costs less:

Well, I mean, obviously it's all about trying new things, but you're part of a space, you pay assistants, you pay for fabrics. Every day that I open the store costs me a certain amount of money, and, in Berlin, at the time I could afford, let's say, a year in my calculations, without earning so much money. In Paris, that year would have been three months. And in three months, with the money I had, I would not have been able to launch a business, so I would have needed that time in order to make my business much more durable in terms of style and business before I could move on (ID07).

The lack of intense economic pressure allows a designer to be more creative and to experiment more, and, because of the relatively small startup capital needed to initiate a label, having more entrepreneurial initiatives. Even if it might lead to mistakes and a related low selling volume, it still will not have a drastic impact on the label. The low living costs also allow patchwork time management in which, alongside the label activities, the designer earns additional money with a part-time job that somehow finances the living costs and entrepreneurial activities.

The second central element recognised by fashion designers in their relation with Berlin is the presence of fashion events and trade fairs that contribute to making it a fashion city. In a broader sense, Berlin offers creative stimuli to designers via local artistic activity as well as through the presence of young and cosmopolitan people. Therefore, it is not possible to consider discrete urban elements as creative inspiration without considering the general context and the creative field, comprised of social and emotional interactions, as well as the personal dimension. Berlin is characterised by the activity of many artists, which has the capacity to stimulate the work of fashion designers and connect it with the urban context of diffuse creativity:

You can meet a lot of creative people here, also a lot who do creative innovative stuff, new stuff (...). At least you know there is someone and another one there, you have heard something, read something, there was an exhibition, another one here. Everyone is so young and so independent (ID03).

In this sense, artistic activity as well as museums and exhibitions are elements that contribute to the creative development and stimulation of the designer. However, it would be incorrect to consider them in a causal relation with creativity (of the designer).

The presence of many young people is reflected in the lively night life and leisure activities, as well as in artistic experimentation: 
Designers in London and designers in Paris and designers in New York are definitely coming to Berlin to see what's going on, because Berlin is very famous for its underground culture, is very famous for its street culture and also for its diversity and openness, obviously. So, if you are a good designer, anywhere in the world, Tokyo or Milan, you're coming to Berlin in one way or another, to see what's going on. And we are really lucky to live here, because not only we have the people who live here, but we have people from all around the world who are coming and experiencing this (ID20).

As the third element, in different interviews, the uniqueness of Berlin among German cities emerges as a creative element for designers. This is due, on the one hand, to the feeling of living in an international and young metropolis and, on the other hand, to the daily life and its influence on creative work in general. Everyday life, with its (real or potential) interaction with different cultures and consequently culturally-influenced places, offers designers stimuli for reflection and feelings that can then be conveyed in their work:

Because it is a nice inspiring city, it is very comfortable to live here, so free, so creative. In Germany, it is, in my opinion, the only place where it is fun. It's always becoming more international, it is a metropolis. If I lived in the countryside, I would surely make different clothes than in the city. Yes, to me, it is always a new inspiration, and also the public that I want to reach (ID19).

Therefore, as presented by fashion designers, there are different elements of the urban context that work to create a specific, local atmosphere which helps them in their creative processes.

However, the creative process and the development of new ideas is not only related to specific elements of the city and its social life, but also to personal and other experience, such as media (e.g. books, movies), fabrics, previously designed collections, travel, or the emotional world of a designer. Another possible inspiration source is offered by communication within the label or with partners, but it might also be that, even to designers, it is unclear where their creative ideas come from.

\section{Conclusions}

On the basis of the data provided, it is possible to recognise the sectoral and spatial dynamics of fashion design in Berlin and - more precisely the existing relations not only between creative actors (fashion designers) and the creative field, but also between the city and the creative field. In this sense it is necessary to underline elements of the urban context that are considered relevant by the designers for their creative work and that might contribute to their location decision.

The first is the concentration in Berlin of other creative actors, both of fashion design and other creative sectors, as well as a diversified cultural offer. Concentrated in the city are relevant cultural and fashion institutions (like museums and fashion schools), events like the Fashion Week that take place regularly, furthermore Berlin has the highest concentration of fashion designers in Germany and is also a place where many other creatives live and work. The presence of those actors and institutions is recognised by fashion designers as an important stimulus for their creative work.

The second element of the city that contributes to creating the creative field and is acknowledged by the designers as having a positive effect on their creativity is the socio-cultural variety and the relatively young age of Berlin inhabitants. The presence of a young and international population sharing a multicultural environment affects positively the work of fashion designers.

The third element that attracts creatives and contributes to forming creative stimuli is related to the consequences of the specific historical and economic contingency of the city. In the last 25 years the dominant sectors of the local economy have changed, and living costs are relatively low in the city, and space for both, residential purposes and entrepreneurial activities as well as 'empty' spaces have become available. The designers consider this a relevant aspect that facilitates their creative activity. The perception of this situation has now started to change, as the living costs are felt to be increasing (House of Research 2015), and purveyors of creative activities have started to face their urban location choices from a different perspective, which might lead to repositioning. 
However, the creative field generated in a given city does not automatically provide a dynamic job market for creative and qualified actors, which is a central element in urban economic growth. Consequently, the urban context and its creative field have to be considered in a dynamic combination of variable elements that influence, and are influenced by, each other and that contribute to the structuring of the city's socio-economic development. What remains an open question for the moment is to what extent location decisions of creative actors will be affected when the socio-economic context that makes the city attractive has changed. At the moment, for fashion designers the city's creative field is a result of the socio-economic context rather than of the job market of creative and innovative sectors. It might also be interesting to identify central elements of the creative field for fashion designers in other European cities, as they will probably be slightly different from those identified in Berlin.

As a concluding remark it should be underlined that the relations of both creative actors and a city with the creative field have to be considered in order to understand the development path and the potential of the creative sector in an urban economy, as well as the challenges and issues related to the conversion of a creative potential into a growth element.

\section{References}

Amt für Statistik Berlin-Brandenburg, 2011. Statistisches Jahrbuch. Amt für Statistik Berlin-Brandenburg, Potsdam.

Amt für Statistik Berlin-Brandenburg, 2012a. Einwohnerinnen und Einwohner im Land Berlin am 30. Juli 2012. Statistischer Bericht A15-hj 1/12.

Amt für Statistik Berlin-Brandenburg, 2012b. Wanderungen Berlin 2012. Statistischer Bericht A III 2-j/12.

Amt für Statistik Berlin-Brandenburg, 2012c. Statistisches Jahrbuch. Amt für Statistik Berlin-Brandenburg, Potsdam.

Amt für Statistik Berlin-Brandenburg, 2013. Statistisches Jahrbuch. Amt für Statistik Berlin-Brandenburg, Potsdam.

Amt für Statistik Berlin-Brandenburg, 2014. Statistisches Jahrbuch. Amt für Statistik Berlin-Brandenburg, Potsdam.

Amt für Statistik Berlin-Brandenburg, 2015. Statistisches Jahrbuch. Amt für Statistik Berlin-Brandenburg, Potsdam.

Bagwell S., 2008. Creative clusters and city growth. Creative Industries Journal 1: 31-46.

Berlin Partner, 2013. Modestandort Berlin. Designer, Messen, Netzwerke. Berlin Partner GmbH, Berlin.

BMWi, 2012. Monitoring zu ausgewählten wirtschaftlichen Eckdaten der Kultur- und Kreativwirtschaft 2011. Bundesministerium für Wirtschaft und Technologie, Berlin.
BMWi, 2015. Monitoring zu ausgewählten wirtschaftlichen Eckdaten der Kultur- und Kreativwirtschaft 2014. Bundesministerium für Wirtschaft und Energie, Berlin.

Boschma R.A., 2004. Competitiveness of regions from an evolutionary perspective. Rgional Studies 38(9): 1001-1014.

Boschma R.A., Fritsch M., 2009. Creative class and regional growth: Empirical evidence from seven European countries. Economic Geography 85(4): 391-423.

Brenke K., 2007. Rasantes Wachstum der Zahl kreativ Tätiger in Berlin. Wochenbericht des DIW Berlin 31: 493-496.

Brenke K., 2010. Berliner Wirtschaft: Nach langem Schrumpfen auf einem Wachstumspfad. Wochenbericht des DIW Berlin 32: 2-10.

Caspari L., 2015. Was die Mieten bremst und was nicht. http://www.zeit.de/politik/deutschland/2015-03/ mietpreisbremse-mieten-makler-bundestag (accessed 4 Feb. 2016).

Clark T.N., Lloyd R., Wong K.K., Jain P., 2002. Amenities drive urban growth. Journal of Urban Affairs 24(5): 493515.

Enquete-Kommission, 2007. Schlussbericht zur Kultur in Deutschaland. Deutscher Bundestag, Berlin.

Evans G., 2009. Creative cities, creative spaces and urban policy. Urban Studies 46 (5-6):1003-1040.

Florida R., 2002. The rise of the creative class. Basic Books, New York.

Glaeser E., 2005. Smart growth: education, skilled workers $\mathcal{E}$ the future of cold-weather cities. Policy Briefs, Harvard University, John F. Kennedy School of Government.

Geppert K, Mundelius M., 2007. Berlin als Standort der Kreativwirtschaft immer bedeutender. Wochenbericht des DIW Berlin 31: 485-491.

Gornig M., 2012. Berliner Wirtschaft: nach Teilung und Transformation auf Wachstumskurs? Zeitschrift für amtliche Statistik Berlin Brandenburg 4: 42-47.

Gornig M., Häussermann H., 2002. Berlin: Economic and spatial change. European Urban and Regional Studies 9: 332-341.

Gornig M., Kolbe J., Bode R., 2012. Datenanalyse zur Berliner Wirtschaft. Deutsches Institut für Wirtschaftsforschung (DIW Berlin), Berlin.

Hall P., 1998. Cities in civilization. Phoenix, London.

Heebels B., van Aalst I., 2010. Creative cluster in Berlin: Entrepreneurship and the quality of place in Prenzlauerberg and Kreuzberg. Geografiska Annaler, Series B 92(4): 347-363.

Hoffmann N., Lompscher K., 1998. Milieu, Netzwerke, Verflechtungen. Ansatzpunkte für die Untersuchung regionalwirtschaftlicher Umbruchsprozesse in Deutschland Osten? Ideenskizze zu einem Forschungsdesign. In: Matthieses U. (ed.), Die Räume der Milieus: Neue Tendenzen in der sozial- und raumwissenschaftlichen Milieuforschung, in der Stadt- und Raumplanung. Sigma, Berlin: 247-264.

House of Research, 2015. Kultur- und Kreativwirtschaftsindex Berlin-Brandenburg 2015. Stimmungslage, Standortbewertung und die Entwicklung seit 2011. House of Research $\mathrm{GmbH}$, Berlin.

Jacobs J., 1961. The death and life of great American cities. Random House, New York.

Krätke S., 1999. Berlin's regional economy in the 1990s: Structural adjustment or 'open-ended' structural break? European Urban and Regional Studies 6(4): 323-338.

Krätke S., 2004. City of talents? Berlin's regional economy, socio-spatial fabric and "worst practice" urban govern- 
ance. International Journal of Urban and Regional Research 28(3): 511-529.

Krätke S., 2011. The creative capital of cities. Interactive knowledge creation and urbanization economies of innovation. Wiley-Blackwell, Chichester.

Krätke S., Borst R., 2000. Berlin: Metropole zwischen Boom und Krise. Leske \& Budrich, Opladen.

Landry C., 2000. The creative city. A toolkit for urban innovators. Comedia Earthscann, Sterling.

Mandel B., 2007. Die neuen Kulturunternehmer. Ihre Motive, Visionen und Erfolgsstrategien. Transcript, Bielefeld.

Merkel J., 2008. Kreativquartiere. Urbane Milieus zwischen Inspiration und Prekarität. Sigma, Berlin.

Merkel J., 2012. Kreative Milieus. In: Eckardt F. (ed.), Handbuch Stadtsoziologie. Springer VS, Wiesbaden: 689-710.

Molotch H., 1996. LA as product: How art works in a regional economy. In: Scott A.J., Soja E.W. (eds), The city: Los Angeles and urban theory at the end of the twentieth century. University of California Press, Berkeley, CA: 225-275.

Moretti E., 2012. New geography of jobs. Houghton Miffin Harcourt Publishing Company, New York.

Mundelius M., 2008. The reliance of Berlin's creative industries on milieus. VDM Verlag, Saarbrücken.

Pratt A., 2005. Cultural industries and public policy. An oxymoron? International Journal of Cultural Policy 11(1): 31-44.

Pratt A., 2008. Creative cities: The cultural industries and the creative class. Geografiska Annaler, Series B, Human Geography 90(2): 107-117.

Scott A.J., 2006a. Creative cities: conceptual issues and policy questions. Journal of Urban Affairs 28(1): 1-17.

Scott A.J., 2006b. Geography and economy. Three lectures. Clarendon Press, Oxford.

Scott A.J., 2008. Social economy of the metropolis: Cognitive-cultural capitalism and the global resurgence of cities. Oxford University Press, New York.
Scott A.J., 2010. Cultural economy and the creative field of the city. Geografiska Annaler, Series B, Human Geography 92(2):115-130.

Scott A.J., 2014. Beyond the creative city: Cognitive-cultural capitalism and the new urbanism. Regional Studies 48(4): 565-578.

Senat WiTF, 2005. Kulturwirtschaft in Berlin. Entwicklungen und Potenziale. Index $\mathrm{GmbH}$, Berlin.

Senat WiTF, 2008. Kulturwirtschaft in Berlin. Entwicklungen und Potenziale. Index $\mathrm{GmbH}$, Berlin.

Senat WiTF, 2014. Dritter Kreativwirtschaftsbericht. Entwicklung und Potentiale. Senatsverwaltung für Wirtschafts, Technologie und Forschung, Berlin.

Staber U., 2008. Network evolution in cultural industries. Industry and Innovation 15(5): 569-578.

Statistische Ämter des Bundes und der Länder, 2016. Bruttoinlaandsprodukt, Bruttowertschöpfung in den Ländern der Bundesrepublik Deutschland 1991 bis 2015. Statistisches Landesamt Baden-Wüttenberg, Stuttgart.

Storper M., 2013. Keys to the city. How economics, institutions, social interaction, and politics shape development. Princeton University Press, Princeton.

Storper M., Scott A.J., 2009. Rethinking human capital, creativity and urban growth. Journal of Economic Geography 9: 147-167.

Stryjakiewicz T., 2010. Location factors of the creative and knowledge-intensive industries in European metropolitan regions. Geographical Journal 62: 3-19.

Stryjakiewicz T., Męczyński M., Stachowiak K., 2014. Role of creative industries in the post-socialist urban transformation. Quaestiones Geographicae 33(2): 19-35.

Youl Lee S., Florida R., Acs Z., 2004. Creativity and entrepreneurship: A regional analysis of new firm formation. Regional Studies 38(8): 879-891.

Zukin S., 1995. The culture of cities. Blackwell Publishing, Oxford. 